\title{
Music and Transcendence: Sufi Popular Performances in East Africa
}

\author{
ANNEMETTE KIRKEGAARD \\ University of Copenhagen
}

\begin{abstract}
The article discusses transcendence in music in relation to popular Sufi performances in East Africa, drawing on specific cases from Zanzibar. Based on fieldwork, it examines ways in which music and movement in a structured event or performance can affect the consciousness. This phenomenon is discussed in close connection to its increasing presence in popular music festivals. The article also addresses the latent conflict between the performative Sufi orders of Islamic faith and the more conservative and increasingly silent Muslims.
\end{abstract}

Keywords: anthropology of music, music and religion, music festivals, popular music studies, African studies

Sufi mysticism has always played a major role in African countries, and the particular qualities of the performative side of Sufi organisations have had a significant impact on social and political history in many parts of the continent. The social framework of Sufi mysticism is organized in Muslim religious brotherhoods, tariqas, which are found all over Muslim Africa, in Morocco and on the Swahili coast, where the present discussion is situated. The tariqas as social units are often united through celebration of a saint or holy man, and they generally and historically have a problematic relation to more formalized kinds of Islamic practices.

In both West Africa and East Africa the tariqas and Sufi cultural organizations provide an important platform for dynamic social mobility, and in the nineteenth and twentieth century they often opposed colonial imperialism (Baderoon 2009). The political implications of this potential antagonism towards the colonial powers are well known and are still active for instance in the Mouride brotherhood in Senegal (McLaughlin 1997). The brotherhoods have also often been in potential conflict with other kinds of Islam; a situation which today is popularly conceived of as a conflict between liberal and fundamentalist Muslims. In most African countries Sufi performances 
have become part of the global music market and are presented in public cultural festivals, as described by Deborah Kapchan in her studies on Moroccan Gnawa (2007).

The popular quality of the Sufi mystics are explained by Abdul Sheriff, according to whom

the religion of the scholarly elite was too legalistic for the common people even in the Islamic heartland. It dealt with rules and regulations for external worship and behaviour, but left an inner void in the spiritual carvings of the heart. In the transition from the folk religions of the littoral people to the new monotheistic religion, especially among the masses, an Islamic institution that played a very important role was the tariqa (path or way) of the Sufi brotherhoods (Sheriff 2010, 244).

According to Sheriff, there was a latent conflict between strict, puritanical forms of Islam and the looser tariqa-sufi version, which the former (for instance in the form of Wahhabism) tried to discipline. In practice, however, 'many ordinary Muslims used both, turning to the ulema for legal matters and correct interpretations of the Sharia, and to the Sufis for everyday devotional matters'. (Sheriff 2010, 244.)

\section{Tariqas in Zanzibar}

Zanzibar, a small island state situated in the Indian Ocean off the coast of Tanganyika and in the nineteenth and twentieth century the seat of the Omani sultans who dominated the area, was in many ways the leading cultural centre of the region; the phenomenon of Sufi brotherhoods spread from here to the mainland (Iliffe 1979, 211-12). The three important waves of tariqas in Tanganyika thus all originated on the coast; the first in the 1880s, the second in 1884 and the third in 1905. The Qadiriyya, believed to be responsible for Islamic revivals in the area, is the oldest and largest of many Islamic brotherhoods (Iliffe 1979, 211). According to the historian Laura Fair, the number of adherents to Sufi brotherhoods, particularly the Qadiriyya, expanded dramatically in Zanzibar at the start of the twentieth century; through its institutions and performative platforms former slaves could raise their social standing in society. 'Unlike the Ibadhi and Shafi'i schools, which dominated Zanzibar during the nineteenth century, status within the Sufi brotherhoods was based on religious devotion rather than heritage or having studied with the most prestigious scholars.' (Fair 2001, 
90.) By this means ' $[t]$ he Mawlid celebrations became vehicles for Islamisation and social re-stratification particularly in Lamu and Zanzibar' (Bang 2003, 22).

The Swahili brotherhoods have often included both men and women. ${ }^{1}$ They thus offer an opportunity to cross the otherwise highly gendered borders of everyday life; even if most events were held in secluded venues, as early as the 1910s women participated actively in Sufi religious rituals, above all in performing the dhikr (Fair 2001, 99). The associations dance, move and sing, and by dancing they induce trance and possession. This possession or trance is close though not identical to the form of worship in the Swahili spirit associations, the chamas, known all over the coast. The chamas are highly institutionalized and use certain kinds of possession crafts, often spoken of as witchcraft. Today they have lost importance in many regions but are still present in Zanzibar. ${ }^{2}$ Even for the devout Muslim the traditional spirits are compatible with Islam, but they are always and by everyone considered inferior to Allah.

Both Anne Marie Schimmel and John Iliffe acknowledge the importance of musical practices in contemporary Sufi rituals; Schimmel actually points out that the Sufis used music as a means in their mission, writing their poetry in the language of the peoples in the lands they came to: '[T] he spread of Islam was not done by fire and sword as most of our sources are wont to say, but rather by the preaching of the Sufis who knew how to win the hearts of the people. And the Sufis wrote their poetry in the language of the people of their lands'. (Schimmel 2003) Iliffe similarly recounts how the tariqas in East Africa were founded by 'disciples of a mystic who taught an esoteric ritual (Dhikr) which the brotherhoods practiced', and speaks of a freed slave called Sheik Ramiya, '[a] man of great magnetism and piety, who drew attention to his organisation by performing the dhikr alone outside his house' (Iliffe $1979,212)$. The obvious romanticism of these quotes notwithstanding, the narratives clearly show that musical performance afforded a special means in spreading the Muslim faith, even if the incitement was ultimately based on economic and social ambitions.

But the merger of music and religions was not always easy and the transcendent elements of the practice of the Sufi tariqas have often been in conflict with more established Muslim institutions.

1 This, however, is partly contradicted by other sources, such as Sheriff 2010.

2 During my fieldwork in Zanzibar in 1994 and 1998, spirits were frequently discussed. 


\section{The term 'Sufi Music' and the Relationship between Music and Sufism}

It is often assumed that Islam generally bans music, but this is a very superficial understanding. Even if restrictions have regularly been imposed, it is frequently stressed that the Qur'an does not simply forbid music. While it is a contested matter and subject to interpretation, it is clear that music has been a close companion, and folktales, literature, organological history, iconography and paintings all point to the repeated presence of music in the Islamic world; in short, musical performance has always held a strong position in the history and development of Islam as a global religion. Significantly, when Islam spread to the Iberian Peninsular in the eighth century the first music school in Europe was founded in Cordoba by the learned Ziryab, who also brought the oud to Al Andalous. (Shiloah 1995, 74.)

The systematization of the so called Haram/Halal dichotomy in music (al Faruqi 1985-86) is often rather confusing, as it is neither a rule nor a law. Nevertheless it clearly refers to the overall compartmentalization of Muslim life, which assists believers in determining whether an activity is good or bad, and is of great importance to the handling of music and dance. These distinctions rest on a number of social features, popularly ranked under the concepts of Zamān (time), Makān (place) and Ikhwān (associates). ${ }^{3}$ Even if the haram/halal distinction is not accepted as law, it is interesting from our point of view that the social 'organisers' of time, place and company in fact create a hierarchy of genres of musical sound, stretching from activities which are Halal, i.e. permissible or legitimate, over controversial phenomena, to those areas of musical life that are explicitly forbidden, i.e. Haram. The most conspicuous example of this interpretive and social definition is perhaps the chanting of the daily prayers and the reading of the Qur'an - the qir'ah, which to Western ears sounds like singing, but is regarded in Islamic thought as 'reading'; it is 'non-musiqa' and therefore

3 In the Zamān perspective is it crucial that the activity does not interfere with the religious duties of a good Muslim, and that the time spent on musical activities is not exaggerated. Again, professional musicians are suspicious as they spend a great deal of time to gain their skill. The Makan of performance must be one that is considered appropriate. Finally, the Ikhwan must comply with notions of honour and dignity in order to be legitimate. (Neubauer \& Doubleday.) 
Halal. ${ }^{4}$ Accordingly, music may be evaluated quite differently according to its zamān, makān and ikhwān; in fact, approval or rejection of music within Islam can be said to be governed by something other than the musical sound itself. In other words, the European idea of autonomous music is conspicuous by its absence.

Finally, the status of the musician plays an important part in evaluating a musical performance. Amateurs who perform music are not susceptible to criticism, while professional musicians are generally regarded with suspicion and sometimes even contempt. It is primarily the commercial aspect of the performance rather than the performance per se which generates this attitude, but it also touches upon the compatibility of being a musician with being a good and devout Muslim. (al Faruqi 1985-86, 16) Many musicians in Zanzibar adhere to an amateur attitude toward music making. ${ }^{5}$

In Sufi mysticism, however, practices and performances generally challenge this hierarchy, as social, religious and secular spaces are fused. The Sufi brotherhoods use cantillation, movements and music as ways to reach Allah, and as Jonathan Shannon has argued they master a specific spiritual practice $(2003,269)$. Their practice of merging indigenous and Islamic traditions is one of the issues that has led to an interpretation of Sufism as popular Islam, and often held to be religious folk music. ${ }^{6}$ In many ways Sufi musical mysticism balances the controversy with their social power, but the brotherhoods hold a difficult position and members have been persecuted and killed. ${ }^{7}$ And they have certainly been mistrusted, precisely because of

4 Beside qur'anic chant, there are three more levels constituting permissible kinds of aural art. This includes family and celebration music, such as lullabies, women's songs and music for weddings, caravan chants, shepherd songs and work songs, and finally military music. Just below the line between legitimate and the questionable forms of music, the upper part consists of free, rhythm vocal and instrumental improvisations, as for instance the taksims. As they stylistically resemble qur'anic chant, they are generally - but not universally - accepted. Below the level of such improvisations are metered vocal and instrumental compositions such as the bashraf - a slow opening movement used all over the Muslim musical world. At the bottom of the questionable level is music of pre-Islamic or non-Islamic origin; folk music or imported modern music. Finally, the lowest level is that of sensuous music, performed in association with condemned activities. This area is clearly and unanimously condemned.

5 Interviews in 1994 and 1998 with Seif Salim Saleh, oud and violin player in the Ikhwan Saafa Musical Club, teacher, composer and writer.

6 In the New Grove Dictionary of Music and Musicians - the primary English-language scholarly reference book in musicology - Sufism is listed under the heading of 'popular Islam' (Neubauer \& Doubleday).

7 The conflicts with colonial powers, nation states and Islamic fundamentalists are many (Parkin 1995). 
their skill and esoteric knowledge in playing and performance. In short, their performative and transcendent culture brings them into potential conflict with stricter kinds of Islam, most recently the rise of Islamic fundamentalism. A typical description of Sufi practices can be found in Shiloah:

[P]hysical movements are performed collectively by initiates all standing in the same line or circle. Shoulder to shoulder, occasionally clapping hands and obsessively repeating fixed phrases, the devotees would sway to and fro in place, raising and lowering themselves, nodding energetically. They sway ever more vigorously, breathing deeply to the modulating voice of the precentor and occasionally to the beating of a drummer or cymbalist. (Shiloah 1995, 141-2.)

It is controversial and the distinctions are sharp; 'dance and physical excitation' are seen as 'methods of reaching an ecstatic trance', but this is often criticized 'because so often the trance was simulated artificially' (Shiloah 1995, 141). In particular, 'their ire was directed especially against the deceitful, exhibitionist dervishes who would dance in the market-place, undress in public, sit on hot coals, swallow glass, engage in acts of self-mutilation and, in general, misuse the ceremony of sama' (Shiloah 1995, 141). As Parkin has emphasized, the conspicuous use of Sufi performance in contemporary tourism recalls this critique and is met with general rejection by Islamic fundamentalism and wahabbism (Parkin 1995).

\section{Musical Transcendence in Contemporary African Sufi Performance}

Drawing on John Blacking's theory that 'the effectiveness of musical symbols depends on human agency' (Blacking 1995, 174), and that musical performances thus assist the process of trance and affect consciousness in context-based ways, I want to argue that there are many different practices of musical transcendence in Muslim Africa. Due to the immanent cultural embeddedness of music in social life and to the acceptance of folk or traditional musics, the forms of music vary significantly. However, the general distinction between trance and ecstasy laid down by Gilbert Rouget is relevant to the present discussion, as it addresses Muslim practices directly. Rouget distinguishes between trance and ecstasy, in that trance is a process in which music transports both listener and performer to a transcendently different state of mind, similar to Kapchan's concept of 'spiritual elevation' (Kapchan 2007); ecstasy or tarab, in contrast, is defined by Rouget as a musical emotion 
which often leads to trance behaviour and which is primarily reached through listening (Rouget 1985, 255 ff.). In Muslim musical practices, the first kind of change of consciousness is related to the ritual of dhikr while the second is found in more reflective and aesthetic kinds of music. The distinction is not exclusive, and as I shall demonstrate some forms are actually mixed.

The central musical form of the trance-side in Rouget's distinction, the dhikr - also sometimes called Zikr and in Kiswahili Zikri - has its origin in Sufi rituals, and it is basically a 'vocalisation of the name of God'. The central word, Allah, is repeated over and over again in order to remember God; the Arabic meaning of the term Dhikr being 'remembrance'. The power of the word is considered huge, and performing it is therefore likewise of extreme importance. The repetitive power of the words is augmented by ecstatic dancing or other kinds of bodily movements and is accompanied by 'appropriate instruments'. Among these Shiloah includes various drums, which provide 'an essential accompaniment that leads to ecstasy by means of an obsessive, exciting beat'. (Shiloah 1995, 143.) Shannon adds the important insight that the ritual works through 'prayer, song and codified bodily movements' and that it can take place everywhere (Shannon 2003, 276).

On the other side of Rouget's scheme is the mood of tarab, translated as ecstasy. Tarab is also the name of a style of popular music, taarab, found on the East African coast; ${ }^{8}$ it generally describes a more refined and 'less extroverted or agitational mode' (Racy 2002, 208). Tarab/taarab is generally not related to body movements and until recently there has been no dancing involved. Taarab, however, is very clearly perceived as a secular music, even if it shares many musical similarities with the music of the mosques and madarasas (Muslim schools). Janet Topp Fargion points to the link: 'Many taarab [popular music style, ed.] singers claim to have learned to sing or to have been discovered in madrasa or Koranic schools. They were often the only "respectable" environments for singing to take place.' (Topp Fargion 2007, 10.)

While in its Swahili version taarab clearly indicates a secular musical form, others, such as the kasida and the dhikr, are always considered sacred. The maulidi celebrations in Zanzibar can include both forms, together with readings of the life story of the Prophet Mohammed. Maulidis do not occur in the mosque alone; they are also an important part of weddings. According to Topp Fargion, local tradition takes two basic forms:

8 Taarab refers to the above-mentioned emotional feeling, not, as is often claimed, to 'something from Arabia'. 
During the month of the birth of the prophet and at other religious occasions, maulidi performances are public events in large open spaces where hundreds of people gather. The readings are unaccompanied and the chapters are interspersed with unaccompanied sung poems (Sw. kasida) in Arabic or Swahili by students from the Koranic schools (madarasa). During weddings, a particular Koranic school is hired. The audience is by invitation only and the event is held at a private home. The readings are less formally linked to the actual texts and more like improvised or memorised poems on a pious theme. The kasida are sung in Swahili and are accompanied on eight round frame drums (Sw. tari; Ar. Tār) of different sizes and pitches. (Topp Fargion 2002, 207.)

The tariqas in Zanzibar are divided into several different orders, whose origins are regarded as closely connected to the trade routes. Their doctrines are seen as tolerant of local customs and are regarded as more egalitarian then clerical Islam. (Fujii 2010, 91.) Their practices are claimed to have influenced other areas of everyday life, and they have obviously grown in popularity during the twentieth century. While they follow Sufi norms differently, according to Fujii they all retain the zikri [dhikr] ritual as their central event. (Fujii 2010,92.) This takes us back to the relationship between music and trance in the dhikr and to Rouget, who clearly identifies the form as trance and 'not an ecstasy, since it manifests itself by movement [...], is produced by sensorial stimuli (sounds), and is achieved not in solitude, but in the company of other participants' (Rouget 1985, 262). Rouget further distinguishes between solitary dhikr and collective dhikr. The first is carried out by means of a special way of breathing and is almost silent. The 'collective' dhikr, or dhikr 'of the commoners', is of most interest to us, since it is closely associated with music and dance. (Rouget 1985, 263.) In the practice of the dhikr, according to Rouget, the breath is very important: 'The exercise of the Dhikr reaches its paroxysm: faces streaming with sweat, eyes almost closed, the faithful are drawn into a rhythmic frenzy, and then comes the silence of their ecstasy' (Rouget 1985, 272). He concludes, importantly: '[a]s we have seen, in the dhikr in the strict sense it is characteristic for the adepts to be the musicants of their own trance'.

Rouget's work, though seminal, is dated by now, and many cultural and social elements have changed. In her article 'Sounding the mind - Music and Trance', Judith Becker sums up his most important contributions concerning music and trance. She finds that Rouget's insistence that there are many different kinds of trance, and that they are associated varyingly with music, has proved to be central to subsequent research. The other major outcome 
of Rouget's work is that he puts to rest the assumption - both folkloric and scientific - of a causal relation between certain kinds of music - such as heavy, fast drumming or repetitious melodic phrasing - and certain kinds of trance. The relationship between music and trance is neither causal nor deterministic; one can achieve trance without music; one can listen to music and not go into trance. Yet the two are often associatively linked. In sum, Rouget clearly demonstrated that given the right cultural conditions, any kind of music, whether vocal or instrumental, can lead to trance. (Becker 1994, 41.) This means that music is culturally understood and that codes have to be known in order to understand, internalize and consume the music and reach trance. While this is perhaps not surprising, and is in fact consistent with the basic findings of John Blacking, it is crucial in relation to understanding the increased public use of Sufi trance music at festivals and tourist events.

I now turn to a particular locality and its negotiation of different musical forms in relation to distinctions between the secular/religious, or the sacred/ profane on the one hand, and between the public and the private on the other: the performance of the maulidi at popular festivals in Zanzibar and its connection to transcendental practices.

\section{The Commercial Market and Spiritual Musics: Maulidi ya Homu and the Mtendeni Maulid Ensemble}

The World Music market has recently started including musics that were previously excluded from commercial or public performance. In line with an understanding of the world music market as always requiring something new and different (Feld 1994; Erlmann 1993), from the mid-1990s onward audiences became bored with stereotyped African musics. A spiritual turn emerged, opening the way for the inclusion of oriental musics, a renewed interest in so called 'heritage production', and a return to Sufism and cultural intimacy (Bohlman 1997). The shift in the world music sector, from a preference for rhythm and body to an aestheticized fascination with religious musics gives a clear indication of what is at stake. By further choosing to denote Sufi music as a spiritual rather than a religious phenomenon, a resemblance to a more universalistic new age ideal is indicated, marking it as clearly different from traditional and old-fashioned religious musics. In relation to the specific qualities of trance as a culture-specific (Rouget 1985; Blacking 1995) and bodily codified (Shannon 2003) practice, the possibility 


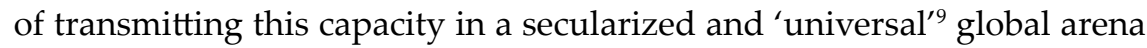
raises new questions.

Philip Bohlman's examination of the meeting between religion and world music is central to understanding how and why a music which is clearly intended for religious absorption can move to other areas of social life and become part of an imagined common spiritual experience. In the promotion of Youssou N'Dour's 2004 release 'Egypt' this spiritual experience is attached to Sufism, which 'by virtue of its inherent popular appeal, has been the emotional doorway to those enrichments' (Nonesuch 2008).

This notion of a popular and open Islam is welcomed by audiences both in the West and in Africa; and while the mystic and secretive aura of the Sufi performers might appear inaccessible, it is nevertheless highly compatible with the demand for exoticism and otherness in the world music market. In the first decade of the twenty-first century, this demand has resulted in a festivalization of musical performances, even religious ones. The marketplace vendors mentioned by Shiolah have perhaps gained new ground. The same trend is also found in Zanzibar, where over the last ten years the celebration of local culture in music festivals has embraced Muslim popular musics - primarily the maulidis and the kasidas from the Muslim/Islamic madrasas - and have brought them into an open, public space.

\section{Case Study: Maulidi ya Homu ya Mtendeni Ensemble}

When I attended the Sauti za Busara festival in Zanzibar in February 2011, one of the highlights for many members of the multinational audience was the performance by the Maulidi ya Homu ya Mtendeni Ensemble. This performance, scheduled between Mali blues and popular Cameroonian dance music, opened with a short recitation from the Qur'an. The front line of young boys and men, dressed in white kanzu and kofia (gowns and hats) and kneeling on the floor, slowly began responding to the rhythm and the calls of the a capella introduction of the khalifa or msomaji 'reader'. As the rhythm gradually grew stronger, the voices increased in a faster rhythm and the row of boys and young men began to move their arms and hands. Chorus parts were sung by a second row of standing men, who slowly began to sway from one side to the other. Later yet these voices and movements were augmented and supported by the sonorous frame drums (matari): Starting out calmly

9 By 'universal' I refer to the general idea that music can cross cultural, religious and social borders, an idea immanent in world music discourse and also subject to Kapchan's examination of the 'sacred' in the Fez Festival (Kapchan 2008). 
and slowly, the 'performance gradually increased in volume, tempo and dynamism of movement, up to an animated climax' (Jahazi media 2011). Gradually also involving the head and the whole body, the choreography was orchestrated by the leader to intensify the singing and the emotion of the performance. The movements grew from small gestures of the hands and the head, reminiscent of Muslim prayer, to 'a fast to and fro clasping each other's arms and rhythmical clapping over the head'. (Jahazi Media 2011.) Sometimes the dancers bent backwards until they were flat on the floor, but they always rose again in perfect synchrony. The movements and their agility were clearly bodily demanding.

The impression was dramatic. The non-stop performance went on for 45 minutes, and the combination of powerful, full-voice singing and the amazing choreographed movements captivated the crowd. Significantly, the experience was and is described in imaginative words by both insiders and outsiders: 'Rolling Waves' (Boswell 2008), 'Snaking, synchronised arm and hand gestures' (Virtual Womex 2011) and 'resembles the sails and the dhows' (Fujii 2010, 93). ${ }^{10}$

The Maulidi ya Homu ya Mtendeni is a young group, but the tradition relates to an old cultural institution of the tariqas and maulidi celebrations in the Arab world. The Maulidi ya Homu is associated with the tariqa Rifa'iyya, which originated in Egypt but has spread across the Near East and as far afield as Indonesia, the Comoros and Zanzibar (Jahazi Media 2011); it is one of the oldest orders in East Africa. Maulidi ya Homu means 'mawlid of the monsoon'; according to its leader Maalim Majid Said Mansur (b. 1930), their zikri ritual expresses the movement of the sail of the dhow (Fujii 2010, 93).

The present tradition was resumed in 1960 on the instructions of former president Arbeid Karume and through the agency of Hajii Barua Ussi. The Mtendeni is one of very few groups that still present this unique tradition (interview with Werner Graebner, Feb 2011) and is the oldest surviving group; it is led to date by Ustadh Majid Said Mansour, who founded the group in the mid-1960s after learning the traditions from his grandfather (Virtual Womex 2011). It is religious music, but while some maulidis are read in mosques, the particular forms of the Mtendeni are not: 'Maulidi ya Homu is an art form and we are artists, it is not played in mosques', said Farhan Mussa, claiming that maulidi is now as much about art as about religious devotion. One of the reasons for this development is that Maulidi

10 This resembles the Sufi group Deba, which was showcased at Womex Copenhagen 2009. Their movements, like those of the Maulidi ya Homu, were said to resemble the waves of the sea. The two cultures are probably closely connected. 
ya Homu has been reclaimed and developed as a cultural and not a religious activity. (Boswell 2008.)

The music of the Zanzibari maulidi groups was first recorded in the 1950s by Hugh Tracey, and has since reached international audiences through field recordings by Janet Topp Fargion (2001) and the Swedish producer Sten Sandahl (1997). With regard to the singing style, Janet Topp Fargion informs us that local styles are of relevance and that ' $[\mathrm{t}] \mathrm{he}$ influence of this performance tradition is perhaps most vividly heard in the long vocal melismas performed by the Sheikh. The ability to improvise long phrases (kumawili in Swahili) is a highly prized skill noted in taarab singers too.' (Topp Fargion 2007, liner notes 10.) The maulidi groups perform kasida, maulidi poems or dhikr; the Mtendeni group in particular is performed during various social celebrations, such as weddings, birth celebrations and circumcision ceremonies (Jahazi Media 2011). A distinctive form of maulidi, a performance celebrating the birth and life of the Prophet Muhammad, is also common, in which the "qasida "praise poems" are sung in a medley-like fashion, one merging into the next', in either Arabic or Kiswahili (Jahazi Media 2011). Finally, Farhan Mussa explains that maulidis also serve another purpose: 'when someone is possessed by spirits we sing to calm the spirits down', (Boswell 2008). This brings us to potential changes of consciousness and to the appearance of ecstasy which is latent in the performance. The description offered in connection with the Womex presentation highlights this element:

Slowly the rhythm and music builds in intensity, until the right moment, when the musicians take everything to another completely higher level. Provoking new states of consciousness for themselves and all who are present, the show is spiritually charged and spectacular. (Virtual Womex 2011.)

Another description likewise stresses the transcendental aspects of the event, explaining that a momentum occurs in which the performers become 'freer, larger and more confident'. With a clear indication of the dhikr immanent in the performance, the observer notices that the sound and movement 'intensifies to a climax and Allah's name is repeated'. (Boswell 2008.) This testifies to the fact that even if this is perceived as a cultural performance, 'the religious benefits are highlighted, as those hosting the performance hope to receive baraka "blessings" and the social respect of celebrating within a community of Muslims' (Jahazi Media 2011). Interestingly, in the performances of the Zanzibari maulidi groups (at least since the 1980s) the 
singing of kasida and the recital of texts from the Qur'an have merged with the bodily practices of the dhikr. Whether this is a specifically East African form is unclear, but it seems to transgress the division between trance and ecstasy argued by Rouget.

The conspicuous display of the maulidi groups at public events partly targeting tourists and Non-Muslims is a relatively new phenomenon. As one member explains: 'In the past, the group would never have played at a place like Hotel Bwawani but now we play at celebrations like birthdays and weddings' (Boswell 2008). This outing of religious/spiritual performances, however, is not without history, but probably rather a re-invention. According to Anne Bang, after 1902, when the celebration [of the alawiyya tariqa] was reorganized and held on public grounds, it gradually became popular in the public sphere (Bang 2003, 148-50). In fact ' $[t]$ he entire Mawlid set-up is best interpreted as a ritual designated to bring the expression of orthodox devotion out from the private houses and into the public space' (Bang 2003, 149).

\section{Public-popular Sufism in Zanzibar}

In contemporary Zanzibar the interest in and use of expressive religious/ spiritual culture has increased. The promotion of maulidi songs in the public space is encouraged by both insiders and outsiders, clearly as part of a general move to expand the island's thriving cultural tourism. (BBC.) The emergence of cultural institutions dedicated to the promotion and preservation of local cultures, such as the Sauti za Busara and the Zanzibar International Film Festival, are another outcome of this interest. Many agents, both within and outside Muslim communities as well as in the tourist industry, try to promote a romanticized image of Zanzibar, in which musics performed under the headline of Sufism achieve a special role. It is, however, equally a repercussion of the processes of globalization, which challenge citizens and artists to hold on to featured elements of local culture. For two reasons: on the one hand to maintain local values, here related to religious identity and faith and as such crucial to social life, on the other of course to gain the advantage of being part of a global music business, a potential source of income, fame and respect. ${ }^{11}$

As noted, the smooth Sufi sounds are welcomed and even evaluated as politically important. The writer and ethnomusicologist Banning Eyre says

11 The Mtendeni Maulidi Ensemble has travelled far; it has been presented at the Fez Festival in Morocco, and as of the time of writing (autumn 2011) is touring Northern Europe. 
of the effect of Mtendeni's performance: 'It is rare that a religiously inspired display can convey such depth of feeling to outsiders. This group could do more than any politician or spokesman to communicate to Westerners the sweetness and elegance inherent in Islam'. (Banning Eyre, www.afropop. org) The statement echoes the universal appraisal of Sufi music, but it is also important to remember its relevance for local communities: what started out as a clearly foreign import and a means for the spread of Islam in Africa has over time become a distinctly Zanzibari blending of local ngoma traditions and more general Islamic elements (Jahazi Media 2011). The description of particular movements by the Mtendeni group, such as 'Sails and Dhows' or 'Rolling Waves' are likewise good indicators of the localization of an all-Islamic cultural and religious form. Shiloah drawing on Arthur Simon suggests the term 'Africanization of Islamic elements' (Shiloah 1995, 87), and perhaps the Zanzibari maulidi is also one such africanized form - an assumption in accordance with the conclusions drawn by Judith Becker as to Rouget's contribution to the knowledge on trance and transcendence. ${ }^{12}$

In his analysis of Sufi music in Syria, Shannon found that few local people actually listened to Rumi and Sufi dhikr; elements of this tradition were most easily found in restaurants and at international shows presented for global consumption as world music (Shannon 2003, 267). For Shannon, the impact of the World Stage is thus that 'musical practices that are presented as authentic local spiritual traditions obtain their authenticity and locality through their enactment and staging in global performance contexts' (Shannon 2003, 267). Only subsequently do they gain popularity locally.

The important question in relation to the Zanzibari case is whether the inclusion of religious music in world music festivals like the Busara and ZIFF is a sign of a process of secularization, or whether it is - in line with Bohlman's thoughts - a way to clothe the other and design a contrast to an Islam which at the moment is represented in negative images. The ethnomusicologist Bob White has coined the term 'commercial religious music' (2003, 36) for these emerging public performances. What is needed is a general examination of how the move towards a more market-related strategy will affect the transcendental elements in the mystical musics of the Sufi orders.

12 The use of the term 'africanization/africanized' is contested. In Zanzibar the term signals the increased social and cultural power of former slaves in the highly hybrid culture, and is often used by the so called 'African' part of the population; it is less popular in the Asian/Arab part of the culture, where the term 'localized' is preferred. As the term is filled with particular meaning, however, it cannot be dismissed as irrelevant. (Based on discussions with Abdul Sheriff, Stone Town, March 2010.) 


\section{Discussion and Concluding Thoughts}

The slogan for the Fez Festival of Sacred Music is ‘Giving Spirit to Globalization' (Schyler 2001, quoted in Shannon 2003), which foregrounds two of the aspects I have been discussing: on the one hand the global and commercial implications of bringing religious musical forms into the modern public space, on the other the role played by transcendental or spiritual emotions. Shannon finds that world music entrepreneurs are in fact promoting sacred musics as a 'purer' style in comparison with other hybrid world musics. (Shannon 2003, 270.) This means that while World Beat is associated with "globalisation and transnational cultural economies, "sacred music" is the domain of the spiritually authentic and the local' (Shannon 2003, 270). The claim is that what is offered is something 'out of the ordinary'; something which in my interpretation and following Kapchan carries the promise of transcendence. The festival-staged performances and promotion of the Maulidi ya Homu ya Mtendeni certainly have this intention.

According to Shannon, the place of performance is more determining of the 'sacredness' of the performance than the actual repertoire, since the same music and songs can be found in both sacred and profane contexts. The lyrics might be changed, but the procedure confirms the important negotiation over 'time, place, company' which I mentioned at the beginning. Kapchan applies the idea of translation in her analysis of the multitude of sacred music festivals that have occurred in Morocco since 2000, arguing that the primarily Sufi-oriented festivals give the promise of a translation between otherwise separated entities. Like Shannon, Kapchan connects this tendency directly to the World Beat phenomenon, which she claims has been instrumental in creating new auditory practices that prepare audiences to embrace and enact this promise. (Kapchan 2008, 476.) This promise of translation, with its implicit elements of universalism, demonstrates the wish to translate and make sense across national, ethnic and racial borders.

Unlike Fez, The Zanzibari Sauti za Busara festival, is not as such a festival of religious music, and the performance of the Mtendeni Maulidi Ensemble is the odd one out in the event. Even so, it is clear that the spirituality of the performance is important, and that its promise of a change of consciousness reaches out to local as well as international members of the audiences. The festival format, however, seems to contradict these intentions: the performance of the Mtendeni in February 2011 was too short for the group to reach the intended kind of momentum (personal communication from Werner Graebner, Feb. 2011). It was also questionable whether the audience - of which I was a member - was in fact given the right conditions for entering 
a mood which could provide Baraka. They were too far away, and audience sight-lines were actually blocked by monitors at the edge of the stage (see Image 1). Performances can fail, and not all sacred events bring transcendence. 'But the promise of translation cannot fail' as Kapchan notes $(2008,481)$, and in Zanzibar too this may provide the incentive for staging the performance.

It is difficult as yet to evaluate how the transcendent elements of the spiritual or religious musics of Zanzibar will react in the long run to these new kinds of presentation and presence of the marketplace. In the local culture it is not unusual for religious ceremonies to be performed in public and to be visible and audible to passers-by. But it is unclear whether the transcendent practices will be able to survive and develop in the dialogue with a commercial, international festival stage, which - in the words of Jonathan Shannon - increasingly marks off the spiritual from the religious, and which is a format that collides with the organized social and bodily practices of this particular tradition. It is, however, important to examine the situation in its empirical appearance carefully; what we do know is that the tendency to present religious music on stage is no longer merely an exception to the format of the public world music festival, but indeed a given.

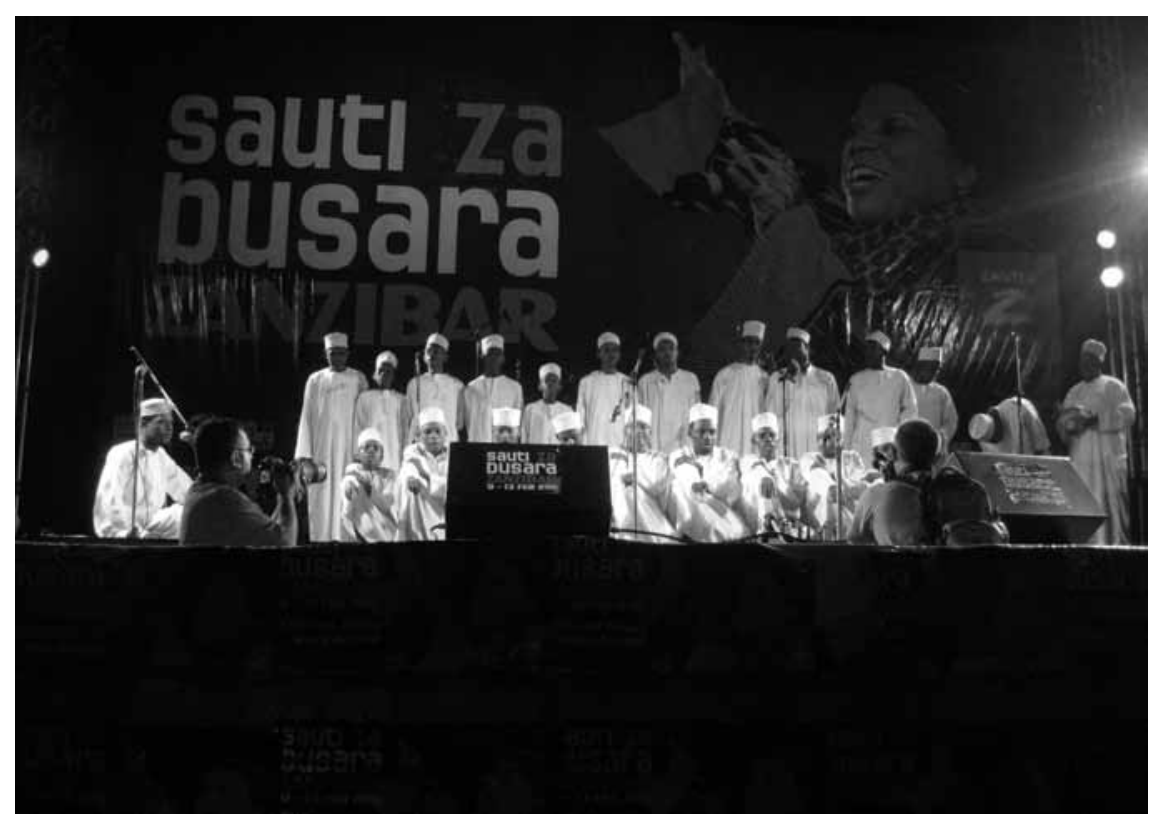

Image 1: The Maulidi ya Homu ya Mtendeni on stage for their 30 minutes showcase performance at Sauti za Busara, February 9th 2011. Photo by the author. 
Bearing in mind the important implications of Gilbert Rouget's theorization of trance - that it is dependent on culturally negotiated and understood codes - the challenge is whether the global embrace of these styles will affect the ability of musical performances to uphold their particularity and their capacity to afford audiences, both locally and globally, the possibility of trance and changes of consciousness. Shannon indicates that a split is emerging and that the Sufi music of Aleppo is undergoing a revival at home due to the global popularity of the Al Kindi group. It is very likely that the outside attention to the story of the Mtendeni group will also create new local agendas; in fact the process has already started, as the Mtendeni is now an officially supported project. In Zanzibar, however, this attention - complex as it might be - must be understood in close connection to the ongoing cultural and religious struggles in society. The conflicting relationship between musical practices and Islamic ideology mentioned in the beginning of this article is still relevant in the Zanzibari present, where some imams and Islamic leaders are protesting against the use of religious music in tourist festivals. (Personal communication from Yusuf Mahmoud, Feb 2010.) Yet maulidi and kasida are still styles primarily used for nontourist purposes, as I saw in wedding celebrations and celebrations of the birthday of the Prophet Mohamed all over Stone Town in February 2011.

Public presentations, in particular those intended for outsiders and ignorant tourists, demand compromise; as in other world music phenomena, some of the locality and speciality of the styles is lost in the negotiations with the world music industry. Language, for one thing, is often reduced to representational relics which indicate an exotic origin but do not reproduce the semantic meaning. Another such compromise are the necessarily strict timetables typical of 'efficient' festival management, which in the case of the Mtendeni performance at Sauti za Busara made it impossible for the group to reach the expected changes of consciousness. Kapchan has shown that the promise of a 'sacred profane' in Morocco is facing similar challenges, and that at the same time as global audiences are rushing to see the romanticized Sufi performers, the very essence of what they are attending for may be lost in the translation. We do not know what will happen to the Maulidi ya Homo ya Mtendeni and their unique cultural-religious tradition of offering baraka and changing consciousness, but it cannot be doubted that the exchange with an international market is a doubled-edged sword: It can provide visibility, renewed attendance and a much-needed economic turnover, but at the same time it can corrupt and diminish the very elements that constitute the identity of the performance. 
Bibliography

\section{al Faruqi, Lois Ibsen}

1985/86 Music, Musicians and Muslim Law. - Asian Music 17 (1), 3-36.

\section{Baderoon, Gabeba}

2009 The African Oceans - Tracing the Sea as Memory of Slavery in South African Literature - Research in African Literature 40 (4), 89-107.

\section{Bang, Anne}

2003 Sufis and Scholars of the Sea: Family Networks in East Africa, 1860-1925, London: Routledge.

\section{Becker, Judith}

1994 Sounding the Mind. Music and Trance - Leonardo Music Journal 4, $41-51$.

\section{Blacking, John}

1995 Reflections on the Effectiveness of Symbols - Reginald Byron (ed.), Music, Culture and Experience: Selected Papers by John Blacking, 174-97. Chicago: University of Chicago Press.

\section{Bohlman, Philip V.}

2003 Music and Cultures; Historiographies of Disjuncture-Martin Clayton \& Trevor Herbert \& Richard Middleton (eds), The Cultural Study of Music. A Critical Introduction, 45-56. New York: Routledge.

1997 World Musics and World Religions: Whose World - Lawrence E. Sullivan (ed.) Enchanting powers. Music in the World's Religions, 61-90. Cambridge, MA: Harvard University Press.

\section{Erlmann, Veit}

1993 The Politics and Aesthetics of Transnational Music - The World of Music 35 (2), 3-15.

\section{Fair, Laura}

2001 Pastimes and Politics: Culture, Community and Identity in Post-abolition Urban Zanzibar, 1890-1945. (Eastern African Studies.) Oxford: James Currey.

\section{Feld, Steven}

1994 Communication, Music and Speech about Music - Charles Keil \& Steven Feld (eds), Music Grooves: Essays and Dialogues, 77-95. Chicago: University of Chicago Press.

\section{Fujii, Chiaki}

2010 Ritual Activities of Tariqas in Zanzibar - African Study Monographs. Suppl. 41, 91-100. 


\section{Iliffe, John}

1979 A Modern History of Tanganyika. Cambridge: Cambridge University Press.

\section{Kapchan, Deborah A.}

2008 The Promise of Sonic Translation: Performing the Festive Sacred in Morocco - American Anthropologist 110 (4), 467-83.

2007 Travelling Spirit Masters; Moroccan Gnawa and Music in the Global Market Place. Middletown: Wesleyan University Press.

\section{McLaughlin, Fiona}

1997 Islam and Popular Music in Senegal: The Emergence of a 'New Tradition' - Africa 67 (4), 560-81.

\section{Parkin, David}

1995 Blank Banners and Islamic Consciousness in Zanzibar - Anthony P. Cohen \& Nigel Rapport (eds), Questions of Consciousness, 198-216. London: Routledge.

Racy, A. J.

2002 Making Music in the Arab World: The Culture and Artistry of Tarab. (Cambridge Middle East Studies.) Cambridge: Cambridge University Press.

\section{Rouget, Gilbert}

1985 [1980 French original] Music and Trance: A Theory of the Relations between Music and Possession. Chicago: University of Chicago Press.

\section{Sandahl, Sten}

1997 Music from Tanzania and Zanzibar 3. Stockholm: Caprice Records.

\section{Shannon, Jonathan $\mathrm{H}$.}

2003 Sultans of Spin: Syrian Sacred Music on the World Music Stage American Anthropologist 105 (2), 266-77.

\section{Sheriff, Abdul}

2010 Dhow Cultures of the Indian Ocean: Cosmopolitanism, Commerce and Islam. London: Hurst \& Company.

\section{Shiloah, Amnon}

1995 Music in the World of Islam: A Socio-Cultural Study. London: Scolar Press.

\section{Topp Fargion, Janet}

2007 Poetry and languid Charm: Swahili Music from Tanzania and Kenya from the 1920s to the 1950s, Topic Records, TSCD936 CD.

2002 The Music of Zenj: Arab-African Crossovers in the Music of Zanzibar - Journal des Africanistes 72 (2), 203-12. 
2001 Zanzibar: Music of Celebration, Topic records, field recordings from 1988. TSCD917, CD.

White, Bob W.

2008 Rumba Rules: The Politics of Dance Music in Mobuto's Zaire, Durham: Duke University Press.

\section{Internet Sources}

\section{Boswell, Frederica}

2008 Poems for the Prophet in Zanzibar, BBC Focus on Africa magazine. <http://news.bbc.co.uk/2/hi/africa/7646108.stm>, accessed August 25, 2011.

\section{Jahazi media}

2011 Mtendeni Maulid Ensemble. < http://www.jahazi-media.de/mtendeni. html >

\section{Neubauer, Eckhard \& Veronica Doubleday}

Islamic Religious Music. - Grove Online. Oxford Music Online, <http://www. oxfordmusiconline.com/subscriber/article/grove/music/52787>, accessed November 2008.

\section{Nonesuch}

2008 Youssou N'Dour. <http://www.nonesuch.com/artists/youssou-ndour $>$, accessed August 28, 2010.

\section{Sauti Za Busara}

$2010<w w w . b u s a r a . o r g>$, accessed August 29, 2010.

\section{Schimmel, Anne-Marie}

1997 Sufism and its Influence in Europe. Lecture at Stanford University, May 4 1997, <http://www.naqshbandi.org/events/sufitalk/sufismeu. htm>, accessed September 3, 2006.

\section{Virtual Womex}

2011 Maulidi ya Homu <http://www.womex.com/virtual/busara_promotions/maulidi_ya_homu> 